\title{
Seed anatomy and water uptake and their relation to seed dormancy of Ormosia paraensis Ducke ${ }^{1}$
}

\author{
Breno Marques da Silva e Silva ${ }^{2 *}$, Camila de Oliveira e Silva ${ }^{2}$, \\ Fabiola Vitti Môro ${ }^{3}$, Roberval Daiton Vieira ${ }^{3}$
}

\begin{abstract}
Ormosia paraensis Ducke has ornamental seeds widely used in the manufacture of bio-jewels and wood used in the furniture industry. For seedling production, the information on its seed physiology is scarce. Thus, the aim of this study was to assess methods for breaking dormancy and relate them to integument structure and water uptake by $O$. paraensis seeds. Seed dormancy-breaking was performed by mechanical scarification and soaking in sulfuric acid for 0, 15, 30, 60, 120, and 240 minutes. Dormancy-broken seeds were compared with intact seeds. Seed integument is formed by a cuticle (hydrophobic substances), epidermis (macroesclereids of the palisade layer,), hypodermis (osteosclereids), and parenchyma cells. Intact seeds did not absorb water after 72 hours of soaking. The highest percentages and rates of seed germination were observed in treatments with mechanical scarification and soaking in sulfuric acid for 60 or 120 minutes. Seed soaking in sulfuric acid $\left(\mathrm{H}_{2} \mathrm{SO}_{4}\right.$ p.a. $\left.98.08 \%\right)$ for 60 or 120 minutes or mechanical scarification are adequate to overcome physical dormancy associated with $O$. paraensis seed integument impermeability to water or gases.
\end{abstract}

Index terms: breaking dormancy, germination, scarification, Fabaceae (Leguminosae).

\section{Anatomia de sementes e absorção de água e sua relação com a dormência de sementes de tento (Ormosia paraensis Ducke)}

\begin{abstract}
RESUMO - Ormosia paraensis Ducke, conhecida popularmente por tento, possui sementes ornamentais amplamente usadas na confecção de biojóias, assim como, sua madeira é usada na indústria moveleira. Para produção de mudas, as informações sobre a fisiologia das sementes de tento são escassas. Desta forma, o objetivo da presente pesquisa foi avaliar métodos para a quebra de dormência, assim como, relacioná-los com a estrutura do tegumento e com a absorção de água pelas sementes. Para a quebra de dormência das sementes, foi utilizada a abrasão com lixa e a imersão em ácido sulfúrico por $0,15,30,60$, 120 e 240 minutos em comparação com sementes intactas. A semente de tegumento é formada pela cutícula (substâncias hidrofóbicas), epiderme (camada paliçada - macroesclereides), hipoderme (osteoesclereides) e células parênquimáticas. As sementes intactas não absorveram água após 72 horas de imersão. As maiores porcentagens e taxas de germinação de sementes foram observadas nos tratamentos de escarificação mecânica e imersão em ácido sulfúrico por 60 ou 120 minutos. A imersão em ácido sulfúrico $\left(\mathrm{H}_{2} \mathrm{SO}_{4}\right.$ - p.a. - 98,08\%) por 60 ou 120 minutos ou a abrasão mecânica com lixa são adequadas para a superação de dormência física associada à impermeabilidade do tegumento das sementes de tento a água ou gases.
\end{abstract}

Termos para indexação: quebra de dormência, germinação, escarificação, Fabaceae (Leguminosae).

\section{Introduction}

Timber use is a very small fraction of the multiple nontimber forest uses, such as handicrafts, production of oils, resins, and dyes, folk medicine and holotherapy, food, and afforestation and landscaping, among others, of Fabaceae species (Ferreira et al., 2005; Chevreuil et al., 2011). However, there is a shortage of information on the Amazonian forest

${ }^{1}$ Submitted on 03/26/2017. Accepted for publication on 04/11/2018.

${ }^{2}$ Universidade do Estado do Amapá (UEAP), 68900-070 - Macapá, AP, Brasil.

${ }^{3}$ Universidade Estadual Paulista "Júlio de Mesquista Filho" (UNESP), 14884-900 - Jaboticabal, SP, Brasil.

"Corresponding author $<$ breno.silva@ueap.edu.br> 
species aiming at the domestication and potentialization of their use for the Amazon and Brazilian economy.

Among the Fabaceae forest species, Ormosia paraensis Ducke is a characteristic tree species of the dense ombrophilous and secondary forests of the Amazon used for timber purposes in the civil construction and furniture production, recovery of degraded areas, and production of handicrafts with seeds (Barros et al., 2009; Castro et al., 2012; Ribeiro et al., 2013).

Seeds of $O$. paraensis are stenospermic, bitegumented, exalbuminous, rounded, bicolored (red and black), have average dimensions of $12.36 \times 9.68 \times 8.03 \mathrm{~mm}$ (length $\times$ width $\times$ thickness) and dry matter content of $0.45 \mathrm{~g}$. seed $^{-1}$. Seed integument is formed by four distinct layers: cuticle (coating with hydrophobic substances), epidermis (with a layer of compact palisade consisting of radially elongated macrosclereids and densely thickened cell walls), hypodermis (hourglass cells or osteosclerotids), and parenchyma cells (Silva et al., 2015).

Most of the Ormosia Jacks seeds are ornamental, hard, and red-colored, commonly with a black spot and rarely yellow. Because of their hardness and resistance, seeds of several Ormosia species are used for making handicrafts. However, this hardness hinders seed analysis and seedling production (Lopes et al., 2006; Gonçalves et al., 2011; Baigts, 2009; Teixeira et al., 2009; Basqueira et al., 2011; Curiel and Morais, 2011; Gurski et al., 2012; Silva and Moraes, 2012; Silva et al., 2014; Silva et al., 2015; Vargas-Simón et al., 2017).

According to Carvalho and Nakagawa (2012) and MarcosFilho (2015), seeds require a series of endogenous (maturity and hormonal balance) and exogenous factors (water, temperature, and substrate) to germinate. If these factors are favorable for germination and viable seeds do not germinate, they are in a state of dormancy. In seeds, dormancy is caused by integument impermeability to water or gases, presence of germination inhibiting or promoting substances, occurrence of immature embryos, and special requirements of light and temperature, among others (Carvalho and Nakagawa, 2012; Baskin and Baskin, 2014).

Seed dormancy is a natural strategy that maximizes the probability of seedling establishment, limits short-term germination opportunities, and avoids germination when conditions are not favorable (Baskin et al., 2006; Van-Klinken and Goulier, 2013; Baskin and Baskin, 2014).

According to Deminicis et al. (2006), Sautu et al. (2006; 2007), Hu et al. (2009), Van-Klinken and Goulier (2013), and Andreani-Junior et al. (2014), several Fabaceae species are known to have, in most cases, seed integument resistant and impermeable to water or gases. Seed integument impermeability in Fabaceae species is an important feature for species permanence in the field under adverse climatic and pathogen conditions, thus being able to remain viable in the soil for a long period composing a seed bank (Souza and Marcos-Filho, 2001; Deminicis et al., 2006).

Under natural conditions, seeds with impermeability are subject to the action of abiotic (thermal amplitude, precipitation, soil $\mathrm{pH}$, light exposure, and abrasion with soil particles) and biotic (fungi, bacteria, and animals) factors on seed integument, promoting the necessary opening for water uptake and hence germination (Carvalho and Nakagawa, 2012; Baskin and Baskin, 2014). However, seed dormancy in the nursery is one of the main problems for seedling production of forest species (Carvalho and Nakagawa, 2012).

For the seedling production of $O$. arborea (Vell.) Harms, Silva et al. (2014) indicated seed soaking in sulfuric acid (100\%) for 15 minutes to obtain $91 \%$ germination, while Lopes et al. (2006) recommended seed soaking in sulfuric acid for 10 minutes or mechanical abrasion to achieve $96 \%$ germination in O. nitida Vogel seeds. Moreover, for O. macrocalyx Ducke, the indication is the isolated use of mechanical scarification or mechanical scarification followed by gibberellic acid $\left(\mathrm{GA}_{3}\right)$ application to overcome seed dormancy (Vargas-Simón et al., 2017).

Considering the diversity of indications of Ormosia Jacks seeds aiming at seed analysis and seedling production, the aim of this study was to assess methods for breaking seed dormancy and relate them to integument structure and water uptake by $O$. paraensis seeds.

\section{Material and Methods}

Fruits were harvested from ten individuals of $O$. paraensis from the Arivaldo Gomes Barreto Natural Park of Macapá, AP, Brazil. Subsequently, ripe fruits were collected directly from the trees before dispersion, as in Silva et al. (2015).

These fruits were dried in the shade for 24 hours in the Department of Landscaping and Urban Afforestation (SEMAM-PMM, Macapá, AP) and then seeds were manually removed. Subsequently, seeds were sent to the Laboratory of Seeds located at UNESP, Campus of Jaboticabal, SP, Brazil.

Seed water content was determined by drying in an oven at $105^{\circ} \mathrm{C} \pm 3$ for 24 hours, as recommended by the Rules for Seed Testing (RAS) (Brasil, 2009), but with three replications of 10 seeds broken with a plier.

Water uptake curve was determined by soaking in water at $30{ }^{\circ} \mathrm{C}$ for $0,1,3,6,12,24,48$, and 72 hours (Lima et al., 2006) for three replications of 10 seeds without scarification and with mechanical (abrasion with sandpaper) and chemical scarification (soaking in $\mathrm{H}_{2} \mathrm{SO}_{4}$ p.a. $98.08 \%$ for $0,15,30,60$, 120 , and 240 minutes). Subsequently, the percentage of water uptake by seeds was calculated according to the equation UP $=$ 
$[(\mathrm{Mf}-\mathrm{Pi}) / \mathrm{Pi}] \times 100$, where UP is the percentage of water uptake by seeds, Mf is the fresh seed mass after soaking, and $\mathrm{Pi}$ is the fresh seed mass before soaking (Baskin et al., 2006).

For seed germination, the following treatments were performed: intact seed (control), mechanical scarification in the hilum with sandpaper, and chemical scarification by soaking in sulfuric acid $\left(\mathrm{H}_{2} \mathrm{SO}_{4}\right.$ p.a. $\left.98.08 \%\right)$ for $0,15,30,60$, 120 , and 240 minutes and subsequent washing for 10 minutes under running water.

In order to assess seed integument after physical and chemical scarification, seeds were dried at ambient temperature for 24 hours and then mounted on aluminum structures and covered with an 18-nm palladium/gold layer using a Hitachi E102 ion sputter and analyzed in a JEOL JSM 500 scanning electron microscope operated at 2,500 V (Santos, 1996).

Germination tests were set up with five replications of 20 seeds placed between paper sheets in plastic boxes, moistened with 2.5 times their dry weight (Brasil, 2009) with $0.1 \%$ Maxin $\mathrm{XL}^{\circledR}$ aqueous solution, and maintained in germination chambers at $30^{\circ} \mathrm{C}$ and with a photoperiod of eight hours (Silva et al., 2015). At the end of germination test, the percentage of germinated, hard, and dead seeds were assessed and calculated according to Brasil (2009) and Silva et al. (2015).

For germination test, the percentage and average germination time were calculated according to $\mathrm{PG}=\left(\Sigma \mathrm{n}_{\mathrm{i}} / \mathrm{N}\right)$ $\times 100$, where $P G$ is the percentage of germination $(\%), n_{i}$ is the number of seeds germinated on the day, and $\mathrm{N}$ is the total number of germinated seeds (Labouriau, 1983), and AT = $\Sigma n_{i} \times t_{i} / \Sigma n_{i}$, where AT is the average germination time (days), $n_{i}$ is the number of seeds between $t_{i}-1$, and $t_{i}$ is the total number of germinated seeds (Labouriau and Agudo, 1987). Seed germination rate was estimated by GR $=\Sigma n_{i} / \Sigma n_{i} \times t_{i}$, where GR is the seed germination rate $\left(\right.$ days $\left.^{-1}\right), n_{i}$ is the number of seeds between $t_{i}-1$, and $t_{i}$ is the number of days between experiment set up and the observation of the i-th day (Hong et al., 2005). Subsequently, the relative frequency of germination was calculated according to Labouriau and Valadares (1976).

The experimental design was a completely randomized design with 5 replications of 20 seeds for germination test and 3 replications of 10 seeds for the soaking curve. The analysis of variance was performed by means of the F test; when F was significant, mean comparisons were carried out by applying the Tukey's test at 5\% probability level. The respective regression equations were determined for the periods of seed soaking in $\mathrm{H}_{2} \mathrm{SO}_{4}$. Statistical analyses were performed by using the $\mathrm{R}$ program (R Core Team, 2014) through the vegan library (Oksanen et al., 2013).

\section{Results and Discussion}

Seeds of $O$. paraensis showed a water content of $10 \pm$ 1.5\%. Similarly, Silva et al. (2014) and Lopes et al. (2006) reported about 18 and $9 \%$ water content for seeds of $O$. arborea (Vell.) Harms. and O. nitida Vog., respectively.

Intact seeds of $O$. paraensis practically did not absorb water after 72 hours of soaking. However, water uptake in seeds mechanically scarified with sandpaper and soaking in $\mathrm{H}_{2} \mathrm{SO}_{4}$ for 60,120 , and 240 minutes stabilized gradually after 24 hours (Figure 1). For O. nitida, seed water uptake stabilization was observed in 24 hours (Lopes et al., 2006).

Soaking of scarified $O$. paraensis seeds presented a three-phase water uptake pattern, as the concept of Bewley and Black (1994), since a rapid water uptake (phase 1 or log phase) was observed in the first 24 hours, a little water uptake (phase 2 or stationary phase) was observed between 24 and 48 hours, and in the last hours, seeds restarted to absorb water (phase 3) (Figure 1). Similar results were observed by Curiel and Moraes (2011), Basqueira et al. (2011), and Silva et al. (2014) in scarified seeds of $O$. arborea, but with smaller or larger soaking periods.

According to Silva et al. (2015), seed integument of $O$. paraensis has four distinct layers: cuticle (coating with hydrophobic substances), epidermis (with a layer of compact palisade consisting of radially elongated macroesclereids and densely thickened cell walls), hypodermis (hourglass cells or osteosclerotids), and parenchyma cells (Figures 2A-F). According to Choudhury et al. (2009), Hu et al. (2009), Carvalho and Nakagawa (2012), Baskin and Baskin (2014),

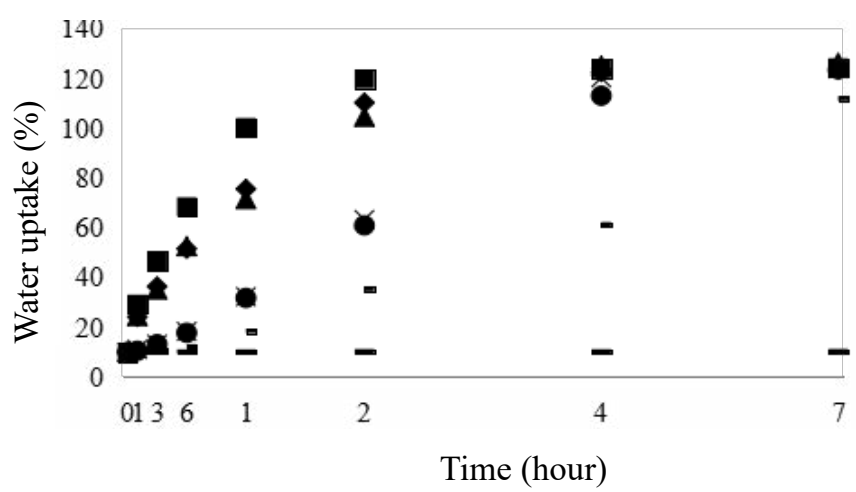

Figure 1. Water uptake curve for intact (control) and chemical $\left(\mathrm{H}_{2} \mathrm{SO}_{4}\right.$ p.a. $\left.98.08 \%\right)$ and mechanically (sandpaper 8) scarified seeds of Ormosia paraensis Ducke maintained immersed in water at $30{ }^{\circ} \mathrm{C}$. Legend: (-) intact, (•) sandpaper, (-) $\mathrm{H}_{2} \mathrm{SO}_{4} 15^{\prime}$,

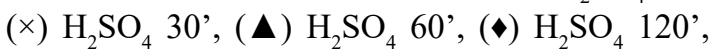
and (घ) $\mathrm{H}_{2} \mathrm{SO}_{4} 240$ '. 
Hudson et al. (2015), and Silva et al. (2015), chemical composition, arrangement, and intercellular substances of the palisade layer influence seed water uptake. Lewis and Yamamoto (1990) reported that lignin is a natural polymer present only in seed coat. However, waxes, suberin, tannin, or even lignin can be found in the cell wall of plants (McDougall et al., 1996).

In non-scarified seeds, the integument was intact (Figures 2A-B). However, water uptake by $O$. paraensis seeds was observed after mechanical scarification due to integument rupture and a consequent exposure of parenchyma cells of the embryo cotyledon (Figures 1 and 2C-D). Vargas-Simón et al. (2017) observed the highest percentages of germination in seeds of $O$. macrocalyx Ducke by means of mechanical scarification or its combination with gibberellic acid, which presented values of 68.0 and $61.3 \%$, respectively.

In seeds chemically scarified with $\mathrm{H}_{2} \mathrm{SO}_{4}$ for 15 minutes, we observed cuticle ruptured and corrosion of macroesclereids of the palisade layer of the integument epidermis (Figures 2E-F). From 30 minutes, we observed cuticle and epidermis

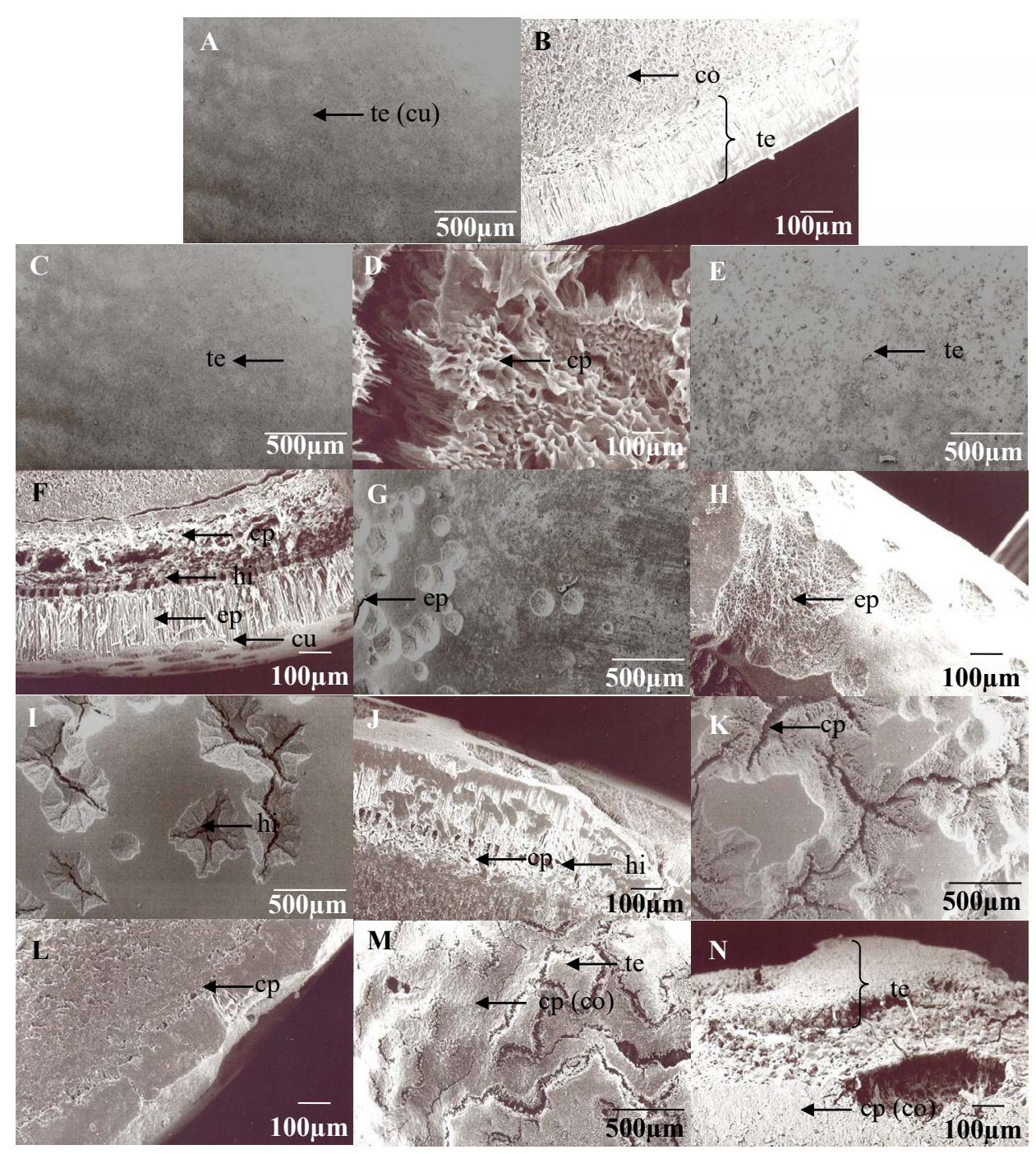

Figure 2. Scanning electromyography of seeds of Ormosia paraensis Ducke: intact seed (A and B), mechanically scarified seed with sandpaper (C and D), and chemically scarified seed with sulfuric acid $\left(\mathrm{H}_{2} \mathrm{SO}_{4}\right.$ p.a. $\left.98.08 \%\right)$ for 15 (E and F), 30 ( $\mathrm{G}$ and $\mathrm{H}), 60$ (I and J), 120 ( $\mathrm{K}$ and $\mathrm{L}$ ), and 240 ( $\mathrm{M}$ and $\mathrm{N}$ ) minutes. Legend: A, C, E, G, I, K, and M - external view; $\mathrm{B}, \mathrm{D}, \mathrm{F}, \mathrm{H}, \mathrm{J}, \mathrm{L}$, and $\mathrm{N}$ - cross-section; $\mathrm{E}$ and $\mathrm{F}$ - cuticle rupture and corrosion of the epidermis; $\mathrm{G}$ and $\mathrm{H}$ - cuticle and epidermis rupture; I and $\mathrm{J}$ - cuticle, epidermis, and hypodermis rupture and corrosion of the integument parenchyma cells; and $\mathrm{K}$ and $\mathrm{N}$ - integument rupture and corrosion of the cotyledon parenchyma cells. te - integument; co cotyledon; cu - cuticle; ep - epidermis; hi - hypoderm; and cp - parenchyma cells. 
rupture and corrosion of the hypodermis (Figures $2 \mathrm{G}-\mathrm{H}$ ). From soaking in sulfuric acid for 60 minutes, we observed cuticle, epidermis, and hypodermis rupture and corrosion of parenchyma cells (Figures 2I-J). However, from 120 minutes, we observed integument rupture and corrosion of parenchyma cells of the embryo cotyledon in $O$. paraensis seeds (Figures 2K-M) (Silva et al., 2015).

Percentage of germination of $O$. paraensis seeds was low (Table 1) due to the cuticle and palisade layers (Figures $2 \mathrm{~A}-\mathrm{B}$ ) and hence low water uptake (Figure 1) of seeds not scarified. According to Lopes et al. (2006), Gonçalves et al. (2008), Silva and Morais (2012), and Vargas-Simón et al. (2017), seeds of $O$. nitida, $O$. arborea, and $O$. macrocalyx presented low percentages of germination due to the tegument impermeable to water or gases.

The highest percentages of germination (Table 1) were observed in $O$. paraensis seeds scarified with sandpaper and soaked in $\mathrm{H}_{2} \mathrm{SO}_{4}$ for $15,30,60$, and 120 minutes. For seeds of $O$. nitida, O. arborea, and $O$. macrocalyx, Lopes et al. (2006), Gonçalves et al. (2008), and Vargas-Simón et al. (2017) recommended mechanical scarification with sandpaper. However, the recommended soaking period in $\mathrm{H}_{2} \mathrm{SO}_{4}$ is variable according to the species, i.e. a period of 15 to 30 minutes for $O$. arborea (Teixeira et al., 2009; Silva e Moraes, 2012; Silva et al., 2014) and 30 minutes for $O$. nitida (Lopes et al., 2006). Probably, the observed behavior regarding soaking in $\mathrm{H}_{2} \mathrm{SO}_{4}$ among species is associated with the chemical and morpho-anatomical composition of the seed integument (Carvalho and Nakagawa, 2012; Baskin and Baskin, 2014).

Seeds soaked in $\mathrm{H}_{2} \mathrm{SO}_{4}$ for 240 minutes had their germination abruptly reduced since this prolonged period damaged the embryo (Figures $2 \mathrm{M}-\mathrm{N}$ and Table 1). Similarly,
Silva et al. (2014) reported a reduction in seed germination of O. arborea from 60 minutes of soaking in $\mathrm{H}_{2} \mathrm{SO}_{4}$.

For percentage of germination, the maximum point for soaking in $\mathrm{H}_{2} \mathrm{SO}_{4}$ was 113.02 minutes (Figure $3 \mathrm{~A}$ ). Thus, there was a tendency of reducing the percentages of germination in shorter or longer periods of soaking in $\mathrm{H}_{2} \mathrm{SO}_{4}$ due to a lower water uptake and, consequently, a lower seed germination related to integument impermeability (Figures 1 and 2A-B) or damages to seed embryo (Figures $2 \mathrm{M}-\mathrm{N}$ ).

Scarification promoted by $\mathrm{H}_{2} \mathrm{SO}_{4}$ reached seed surface indistinctly (Figures $2 \mathrm{E}-\mathrm{N}$ ) and several areas for water uptake arose. However, in mechanically scarified seeds, with abrasion carried out in seed hilum (Figures 2C-D), we observed a slower initial water uptake, reaching values similar to those observed in seeds soaked in $\mathrm{H}_{2} \mathrm{SO}_{4}$ for 60 and 120 minutes after 72 hours (Figure 1).

Due to differences in water uptake (Figure 1), the highest germination rates were observed in seeds scarified with sandpaper or soaked in $\mathrm{H}_{2} \mathrm{SO}_{4}$ for 60 and 120 minutes when compared to intact seeds and those soaked in $\mathrm{H}_{2} \mathrm{SO}_{4}$ for 15 and 30 minutes (Table 1 and Figure 3B). Seed germination rates were extremely low for seeds soaked in $\mathrm{H}_{2} \mathrm{SO}_{4}$ for 240 minutes when compared to the other soaking periods (Table 1 and Figure 3B).

Seed germination rate presented a maximum point for soaking period in $\mathrm{H}_{2} \mathrm{SO}_{4}$ of 122.15 minutes (Figure 3B). Thus, a tendency of reduction of germination rates was observed in lower or higher soaking periods in $\mathrm{H}_{2} \mathrm{SO}_{4}$ due to a slow water uptake (Figures 1 and $2 \mathrm{~A}-\mathrm{B}$ ) or damages to seed embryo (Figures $2 \mathrm{M}-\mathrm{N}$ ).

Due to the lower water uptake (Figure 1), non-scarified seeds had low germination or its delay, occurring on average at 17.8 days (Figure 4A). Similarly, seeds treated by soaking in $\mathrm{H}_{2} \mathrm{SO}_{4}$ for 15,30 , and 60 minutes (Figures $4 \mathrm{C}-\mathrm{E}$ ) showed higher average germination times when compared to

Table 1. Percentage of germination (PG), hard seeds (HS), dead seeds (DS), and germination rate (GR) of intact (control), chemically $\left(\mathrm{H}_{2} \mathrm{SO}_{4}\right.$ p.a. $98.08 \%$ ), and mechanically (sandpaper) scarified seeds of Ormosia paraensis Ducke maintained between paper sheets in plastic boxes at $30^{\circ} \mathrm{C}$ and photoperiod of 8 hours.

\begin{tabular}{|c|c|c|c|c|}
\hline Treatment & PG (\%) & GR $\left(\right.$ day $\left.^{-1}\right)$ & HS (\%) & DS $(\%)$ \\
\hline Control & $6 \mathrm{c}$ & $0.070 \mathrm{~d}$ & $87 \mathrm{a}$ & $7 \mathrm{c}$ \\
\hline Mechanical scarification (sandpaper) & $80 \mathrm{a}$ & $1.998 \mathrm{a}$ & $0 \mathrm{~b}$ & $20 \mathrm{bc}$ \\
\hline $\mathrm{H}_{2} \mathrm{SO}_{4} 15$ & $75 \mathrm{a}$ & $1.362 \mathrm{~b}$ & $0 \mathrm{~b}$ & $25 \mathrm{~b}$ \\
\hline $\mathrm{H}_{2} \mathrm{SO}_{4} 30$ ' & $81 \mathrm{a}$ & $1.372 \mathrm{~b}$ & $0 \mathrm{~b}$ & $19 \mathrm{bc}$ \\
\hline $\mathrm{H}_{2} \mathrm{SO}_{4} 60$ & $77 \mathrm{a}$ & $1.720 \mathrm{ab}$ & $0 \mathrm{~b}$ & $23 \mathrm{bc}$ \\
\hline $\mathrm{H}_{2} \mathrm{SO}_{4} 120$ & $79 \mathrm{a}$ & $2.076 \mathrm{a}$ & $0 \mathrm{~b}$ & $21 \mathrm{bc}$ \\
\hline $\mathrm{H}_{2} \mathrm{SO}_{4} 240$ & $27 \mathrm{~b}$ & $0.662 \mathrm{c}$ & $0 \mathrm{~b}$ & $73 \mathrm{a}$ \\
\hline LSD & $16.7 *$ & $0.548^{*}$ & $5.7 *$ & $17.6^{*}$ \\
\hline CV $(\%)$ & 13.8 & 20.6 & 23.0 & 32.6 \\
\hline F test & $68.8 * *$ & $35.4 * *$ & $658.1 * *$ & $27.4 * *$ \\
\hline
\end{tabular}

**Significant at $1 \%$ probability by the $\mathrm{F}$ test. *Means followed by the same letter do not differ from each other by the Tukey's test at $5 \%$ probability. 

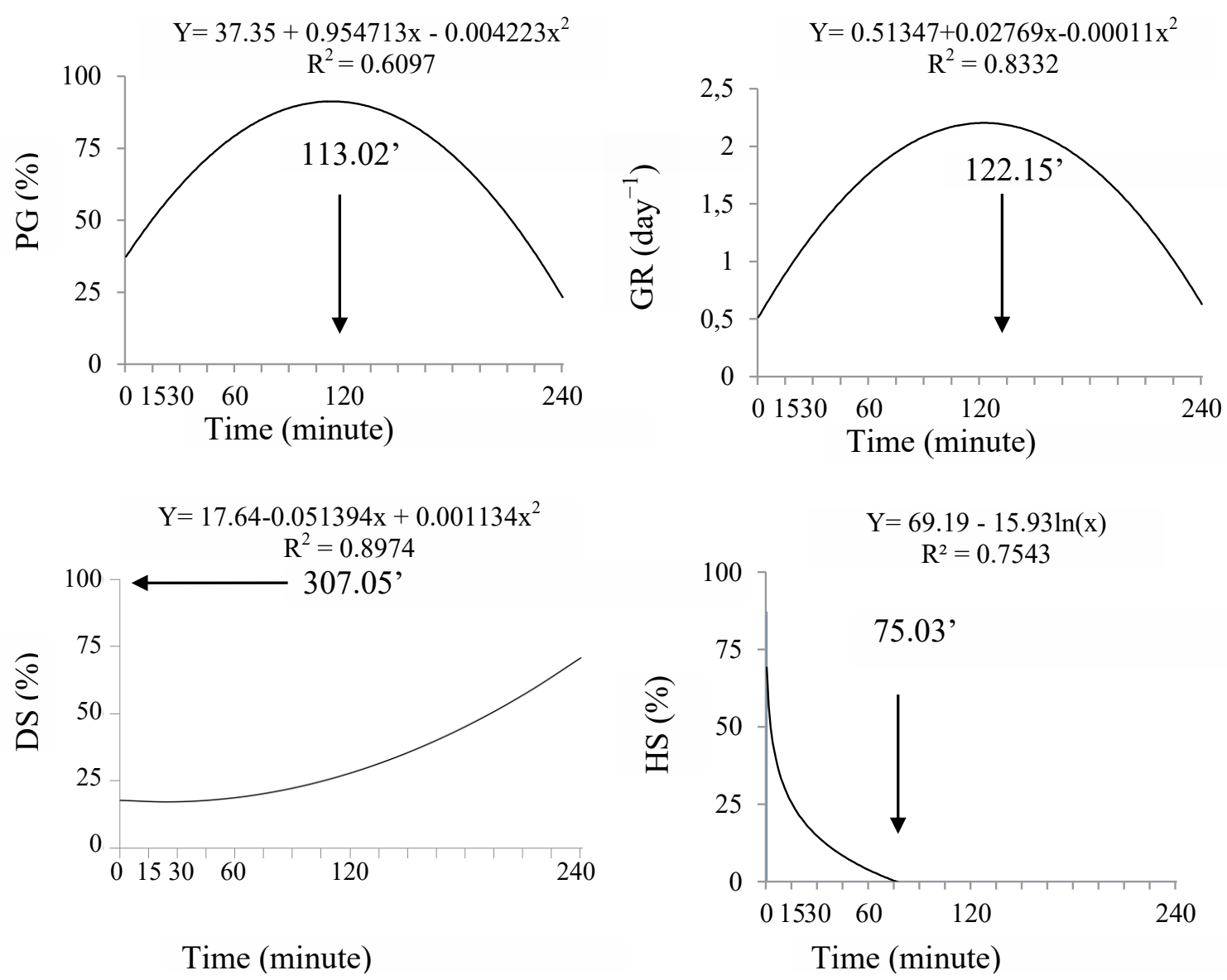

Figure 3. Percentage of germination (PG), germination rate (GR), percentage of hard (HS) and dead (DS) seeds of Ormosia paraensis Ducke. Intact and chemically $\left(\mathrm{H}_{2} \mathrm{SO}_{4}\right.$ p.a. 98.08\%) scarified seeds for 15, 30, 60, 120 or 240 minutes, maintained between paper sheets in plastic boxes at $30^{\circ} \mathrm{C}$ and photoperiod of 8 hours. Test $\mathrm{F}$ at $5 \%$.

sandpaper scarification and soaking in $\mathrm{H}_{2} \mathrm{SO}_{4}$ for 120 and 240 minutes (Figures 4B, F-G). Similarly, Lopes et al. (2006) observed that $O$. nitida seeds treated by soaking in $\mathrm{H}_{2} \mathrm{SO}_{4}$ for $1,5,10,15,20,25$, and 30 minutes presented average germination times similar to and lower than those observed in intact seeds.

The highest synchronies for germination were observed in seeds treated with sandpaper scarification and soaking in $\mathrm{H}_{2} \mathrm{SO}_{4}$ for 120 and 240 minutes (Figures 4B, F-G). Thus, the frequencies of germination of $O$. paraensis seeds in these treatments were more unimodal, while polymodal in other treatments (Figure 4). For O. arborea seeds, the average germination time ranged from 8.2 to 14.8 days for sandpaper scarification plus soaking in water for 5 days and soaking in $\mathrm{H}_{2} \mathrm{SO}_{4}$ for 15 minutes. These treatments exhibited the highest and lowest synchronization, respectively (Silva et al., 2014).

The percentage of hard seeds in both mechanical and chemical scarifications was zero (Figure 3C) whereas non- scarified seeds presented about $87 \%$ hard seeds since they did not absorb water (Figure 1 and Table 1). A similar result was observed by Lopes et al. (2006) in non-scarified seeds of $O$. nitida, as their integument remained intact and hence did not allow water uptake.

The percentage of dead seeds increased quadratically as the soaking period in $\mathrm{H}_{2} \mathrm{SO}_{4}$ increased (Figure 3D) since $\mathrm{H}_{2} \mathrm{SO}_{4}$ passed through the integument and corroded seed embryo (Figures 2M-N). In addition, after about 307.05 minutes of soaking, seeds were totally killed by the corrosive action of $\mathrm{H}_{2} \mathrm{SO}_{4}$ (Figure 3D). According to Lopes et al. (2006), the $\mathrm{H}_{2} \mathrm{SO}_{4}$ action also increased the number of dead seeds in $O$. nitida.

Seeds chemically or mechanically scarified absorbed water and most of them germinated. In contrast, intact seeds had a low percentage of uptake and germination (Figure 1 and Table 1). Thus, an exponential tendency was observed for dormancy release, whose point of intersection of the equation 

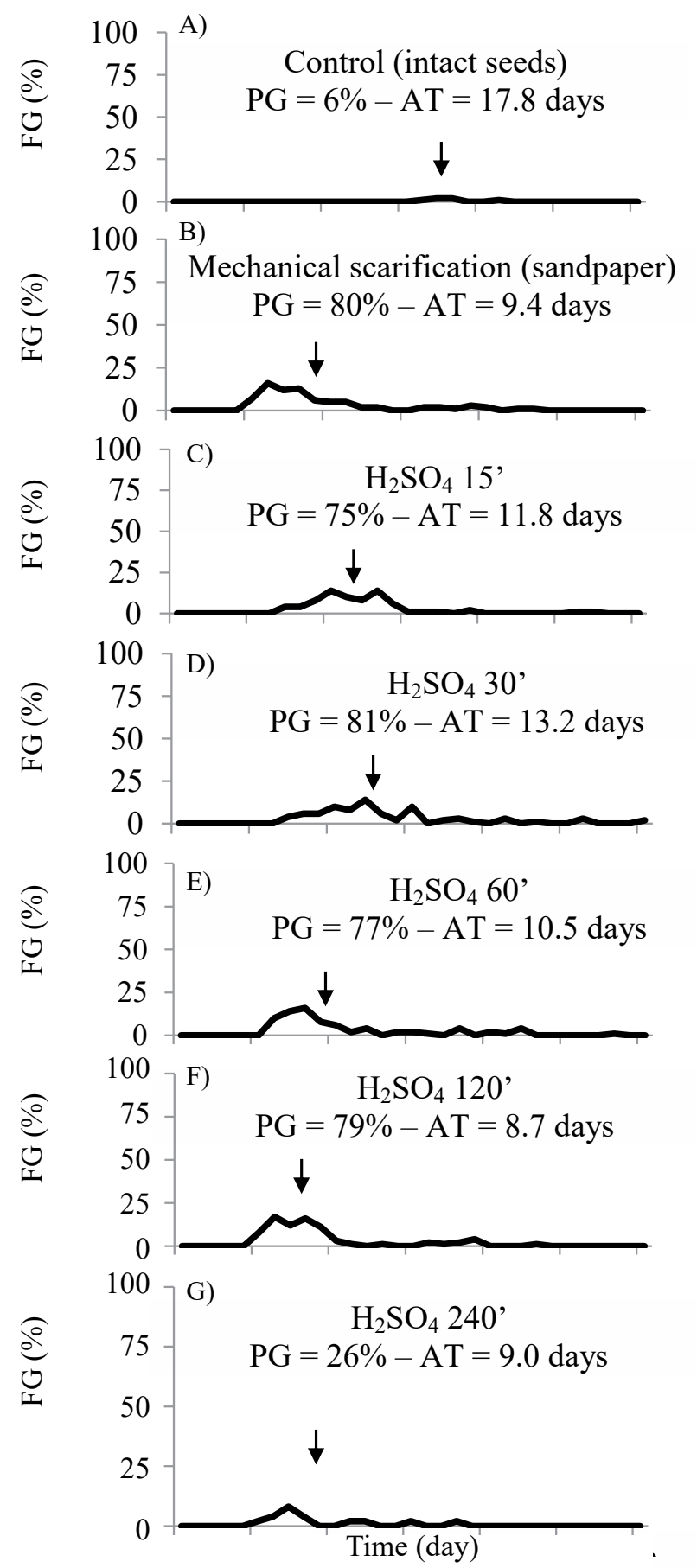

Figure 4. Frequency of germination (FG) of intact (A), mechanically (sandpaper) (B), and chemically scarified $\left(\mathrm{H}_{2} \mathrm{SO}_{4}\right.$ p.a. $\left.98.08 \%\right)$ seeds of Ormosia paraensis Ducke for 15 (C), 30 (D), 60 (E), 120 (F), or $240(\mathrm{G})$ minutes maintained between paper sheets in plastic boxes at $30^{\circ} \mathrm{C}$ and photoperiod of 8 hours. was about 75.03 minutes of soaking in $\mathrm{H}_{2} \mathrm{SO}_{4}$ (Figure 4C).

\section{Conclusions}

Seed soaking in sulfuric acid $\left(\mathrm{H}_{2} \mathrm{SO}_{4}\right.$ p.a. $\left.98.08 \%\right)$ for 60 or 120 minutes or mechanical abrasion with sandpaper are adequate to overcome physical dormancy associated with $O$. paraensis seed integument impermeability to water or gases.

\section{Acknowledgments}

To UNESP for the facilities, equipment, and reagents. To CAPES and CNPq for granting the doctoral scholarship to the first author and the research productivity scholarships to the last two authors. To UEAP for granting of financial assistance for publication.

\section{References}

ANDREANI-JUNIOR, R.; MELLO, W.S.; SANTOS, S.R.G.; KOZUSNY-ANDREANI, D.I. Superação da dormência de sementes de três essências florestais nativas. Revista da Universidade Vale do Rio Verde, v.12, n.1, p.470-479, 2014. http://dx.doi.org/10.5892/ ruvrd.v12i1.1390

BAIGTS, C.R.B. Semillas utilizadas para elaborar artesanías lacandonas en Chiapas, México. Lacandonia, v.3, p.45-58, 2009. http://cuid.unicach.mx/revistas/index.php/lacandonia/article/ view/171

BARROS, S.V.S.; PIO, N.S.; NASCIMENTO, C.C.; COSTA, S.S. Avaliação do potencial energético de duas espécies florestais Acacia auricoliformis e Ormosia paraensis cultivadas no município de Irantuba/Amazona, Brasil. Madera y Bosques, v.14, n.2, p.59-69, 2009. http://www.scielo.org.mx/pdf/mb/v15n2/v15n2a4.pdf

BASKIN, C.C.; BASKIN, J.M. Seeds: ecology, biogeography, and evolution of dormancy and germination, 2ed. San Diego, CA, USA: Academic/Elsevier. 2014. 666p.

BASKIN, C.C.; THOMPSON, K.; BASKIN, J.M. Mistakes in germination ecology and how to avoid them. Seed Science Research, v.16, p.165-168, 2006. https://doi.org/10.1079/SSR2006247

BASKIN, J.M.; BASKIN, C.C.; DIXON, K.W. Physical dormancy in the endemic Australian genus Stylobasium, a first report for the family Surianaceae (Fabales). Seed Science Research, v.16, p.229232, 2006. https://doi.org/10.1079/SSR2006248

BASQUEIRA, R.A.; PESSA, H.; SOUZA-LEAL, T.D.; PEDROSODE-MORAES, C. Superação de dormência em Ormosia arborea (Fabaceae: Papilonoideae) pela utilização de dois métodos de escarificação mecânica em diferentes pontos do tegumento. Revista em Agronegócio e Meio Ambiente, v.4, p.547-561, 2011. http:// periodicos.unicesumar.edu.br/index.php/rama/article/view/1876 
BEWLEY, J.D.; BLACK, M. Seeds: Physiology of Development and Germination. Plenum Press, New York, 1994. 445p.

BRASIL. Ministério da Agricultura, Pecuária e Abastecimento. Regras para análise de sementes. Ministério da Agricultura, Pecuária e Abastecimento. Secretaria de Defesa Agropecuária. Brasília, DF: MAPA/ACS, 2009. 395p. http://www.agricultura.gov.br/arq_editor/ file/2946_regras_analise_sementes.pdf

CARVALHO, N.M.; NAKAGAWA, J. Sementes: ciência, tecnologia e produção. 5ed. Jaboticabal: FUNEP, 2012. 588p.

CASTRO, J.P.; MADY, F.T.M.; HIGUCHI, N.; VASCONCELLOS, F.J.; FREITAS, J.A.; SILVA, B.N.S. Caracterização das madeiras denominadas de pau-de-escora comercializadas na cidade de Manaus, Amazonas. Cerne, Lavras, v.18, n.4, p.557-563, 2012. http://dx.doi.org/10.1590/S0104-77602012000400005

CHEVREUIL, L.R.; GONÇALVES, J.F.C.; SCHIMPL, F.C.; SOUZA, C.S.C.R.; SOUZA, L.A.G.; PANDO, S.C. Prospecção de inibidores de serinoproteinases em folhas de leguminosas arbóreas da floresta Amazônica. Acta Amazonica, v.41, n.1, p.163-170, 2011. http://www.scielo.br/pdf/aa/ v41n1/a19v41n1.pdf

CHOUDHURY, B.I., KHAN, M.L.; DAS, A.K. Seed dormancy and germination in Gymnocladus assamicus: An endemic legume tree from Northeast India. Seed Science \& Technology, v.37, p.582-588, 2009. https://doi.org/10.15258/sst.2009.37.3.07

CURIEL, A.C.; MORAES, C. Germinação de Ormosia arborea (Vell.) Harms submetida a diferentes períodos de exposição e concentração de GA3 pós escarificação mecânica. Scientia Plena. v.7, p.1-6, 2011. https://www.scientiaplena.org.br/sp/article/view/215

DEMINICIS, B.B.; ALMEIDA, J.C.C.; BLUME, M.C.; ARAÚJO, S.A.C.; PÁDUA, F.T.; ZANINE, A.M.; JACCOUD, C.F. Superação da dormência de sementes de oito leguminosas forrageiras tropicais. Archivos de Zootecnia, v.55, n.212, p.401-404, 2006. https://www. researchgate.net/publication/275335900_Superacao_da_dormencia_ de_sementes_de_oito_leguminosas_forrageiras_tropicais

FERREIRA, G.F.; LEMOS, E.E.P.; SOUZA, F.X.; LOURENÇO, I.P.; LEDERMAN, I.E.; BEZERRA, J.E.F.; JÚNIOR, J. F.S.; BARROS, L.M.; RUFINO, M.S.M.; OLIVEIRA, M.E.B.; MENDONÇA, R.M.N.; ALVES, R.E.; ARAÚJO, R.R.; SILVA, S.M.; SOUZA, A.B. de. Frutíferas. In: SAMPAIO, E.V.S.B. (ed.). Espécies da flora nordestina de importância econômica potencial. Recife: Associação Plantas do Nordeste, 2005. p. 49-100.

GONÇALVES, E.P.; SOARES, F.S.J.; SILVA, S.S.; TAVARES, D.S.; VIANA, J.S.; CARDOSO, B.C.C. Dormancy breaking in Ormosia arborea Seeds. International Journal of Agronomy, v.2011, 5p., 2011. http://www. hindawi.com/journals/ija/2011/ 524709/

GURSKI, C.; DIAS, E.S.; MATTOS, E.A. Caracteres das sementes, plântulas e plantas jovens de Ormosia arborea (Vell.) Harms e Ormosia fastigiata Tul. (Leg-papilionoideae). Revista Árvore, v.36, n.1, p.37-48, 2012. http://www. scielo.br/scielo.php?pid=S0100$67622012000100005 \&$ script $=$ sci_arttext

HONG, T.D.; ELLIS, R.H.; ASTLEY, D.; PINNEGAR, A.E.; GROOT, S.P.C.; RAAK, H.L. Survival and vigour of ultra-dry seeds after ten years of hermetic storage. Seed Science and Technology, v.33, p.449-460, 2005. http://libcatalog.cimmyt.org/download/ reprints/98041.pdf

HU, X.W.; WANG, Y.R.; WU, Y.P.; BASKIN, C.C. Role of the lens in controlling water uptake in seeds of two Fabaceae (Papilionoideae) species treated with sulphuric acid and hot water. Seed Science Research, v. 19, p.73-80, 2009. https://doi.org/10.1017/ S0960258509301099

HUDSON, A.R.; AYRE, D.J.; OOI, M.K. Physical dormancy in a changing climate. Seed Science Research, v.25, p.66-81, 2015. DOI: $10.1017 /$ S0960258514000403

LABOURIAU, L. G. A germinação das sementes. Washington: Secretaria Geral da Organização dos Estados Americanos, 1983. 174p.

LABOURIAU, L.G.; AGUDO, M. On the physiology of germination in seeds in Salvia hispanica L. temperature effects. Anais Academia Brasileira Ciências, v.59, p.37-56, 1987. https://www.scienceopen. com/document?vid=ce7b184b-9298-4d2c-9a58-d0a7158f7ec9

LABOURIAU, L.G.; VALADARES, M.E.B. On the germination of seeds Calotropis procera (Ait.) Ait.f. Anais da Academia Brasileira de Ciências, v.48, n.2, p.263-284, 1976. http://agris.fao.org/agrissearch/search.do?recordID=US201302968715

LEWIS, N.G.; YAMAMOTO, E. Lignin: occurrence, biogenesis and biodegradation. Annual Review of Plant Physiology Plant Molecular Biology, v.41, p.455-496, 1990. http://www.annualreviews.org/doi/ abs/10.1146/annurev.pp.41.060190.002323

LIMA, J.D.; ALMEIDA, C.C.; DANTAS, V.A.V.; SILVA, B.M.S.; MORAES, W.S. Efeito da temperatura e do substrato na germinação de sementes de Caesalpinia ferrea Mart. ex Tul. (Leguminosae, Caesalpinoideae). Revista Árvore, v.30, n.4, p.513-518, 2006. http:// dx.doi.org/10.1590/S0100-67622006000400003

LOPES, J.C.; DIAS, P.C.; MACEDO, C.M.P. Tratamentos para acelerar a germinação e reduzir a deterioração das sementes de Ormosia nitida Vog. Revista Árvore, v.30, n.2, p.171-177, 2006. http://dx.doi.org/10.1590/S0100-67622006000200003

MARCOS-FILHO, J. Fisiologia de sementes de plantas cultivadas. Londrina: ABRATES, 2015, 659p.

McDOUGALL, G.J.; MORRISON, I.M.; STEWART, D.; HILLMAN, J.R. Plant cell walls as dietary fibre: range, structure, processing and function. Journal of the Science of Food and Agriculture, v.70, n.2, p.133150, 1996. DOI: 10.1002/(SICI)1097-0010(199602)70:2<133::AIDJSFA495>3.0.CO;2-4

OKSANEN, J.; BLANCHET, F.G.; KINDT, R.; LEGENDRE, P.; MINCHIN, P.R.; O'HARA, R.B.; SIMPSON, P.S.; STEVENS, M.H.H.; WAGNER, H. Vegan: Community Ecology Package: R package version 2.0-9, 2013. https://cran.r-project.org/web/packages/vegan/index.html

R CORE TEAM. R: a language and environment for statistical computing. Vienna: R Foundation for statistical computing, Vienna, 2014. http://www.R-project.org/

RIBEIRO, R.B.S.; GAMA, J.R.V.; MARTINS, S.V.; MORAES, A.; 
SANTOS, C.A.A.; CARVALHO, A.N. Estrutura florestal em projeto de assentamento, comunidade São Mateus, município de Placas, Pará, Brasil. Revista Ceres, v.60, n.5, p.610-620, 2013. http://dx.doi. org/10.1590/S0034-737X2013000500003

SANTOS, J.M. Microscopia de varredura aplicada às ciências biológicas. Jaboticabal: FUNEP, 1996. 56p.

SAUTU, A.; BASKIN, J.M.; BASKIN, C.C.; CONDIT, R. Studies on the seed biology of 100 native species of trees in a seasonal moist tropical forest, Panama, Central America. Forest Ecology and Management, v.234, p.245-263, 2006. DOI:10.1016/j. foreco.2006.07.006

SAUTU, A.; BASKIN, J.M.; BASKIN, C.C.; DEAGO, J.; CONDIT, R. Classification and ecological relationships of seed dormancy in a seasonal moist tropical forest, Panama, Central America. Seed Science Research, v.17, p.127-141, 2007. DOI:10.1017/ S0960258507708127

SILVA, A.L.; DIAS, D.C.F.S.; LIMA, L.B.; MORAIS, G.A. Methods for overcoming seed dormancy in Ormosia arborea seeds, characterization and harvest time. Journal of Seed Science. v.36, p.318-325, 2014. DOI:10.1590/2317-1545v36n31012

SILVA, A.L.; MORAIS, G.A. Biometry and dormancy breaking of Ormosia arborea seeds. Communications in Plant Sciences. v.2, p.3-4, 2012. http://complantsci.files.wordpress.com/2012/12/ complantsci_2_2_22.pdf
SILVA, B.M.S.; SILVA, C.O.; MORO, F.V.; VIEIRA, R.D. Morphoanatomy of fruit, seed and seedling of Ormosia paraensis Ducke. Journal of Seed Science, v.37, n.4, p.192-198, 2015. http:// dx.doi.org/10.1590/2317-1545v37n4151436

SOUZA, F.H.D.; MARCOS-FILHO, J. The seed coat as a modulator of seed-environment relationships in Fabaceae. Revista Brasileira de Botânica, v.24, n.4, p.365-375, 2001. http://dx.doi. org/10.1590/S0100-84042001000400002

TEIXEIRA, W.F.; RODRIGUES, E.A.; AMARAL, A.F. Estudo de superação de dormência de Ormosia arborea sob diferentes testes, para produção de mudas para reflorestamento de áreas degradadas no município de Patos de Minas, MG. Perquirere - Revista do Núcleo Interdisciplinar de Pesquisa e Extensão do UNIPAM, n.6, p.26-30, 2009. http://www.unipam.edu.br/ perquirere/file/file/2009/Estudo_ de_superacao_de_dormencia.pdf

VAN-KLINKEN, R.D.; GOULIER, J.B. Habitat-specific seed dormancy-release mechanisms in four legume species. Seed Science Research, v.23, p.181-188, 2013. DOI:10.1017/So960258513000196.

VARGAS-SIMÓN, G.; MARTÍNEZ-ZURIMENDI, P.; DOMÍNGUEZDOMÍNGUEZ, M.; PIRE, R. Seed germination in Ormosia macrocalyx, an endangered tropical forest tree. Botanical Sciences, v.95, n.2, p.329-341, 2017. http://www.botanicalsciences.com.mx/index.php/botanicalSciences/ article/view/823 